\title{
Development of the Morphostructure and Meat Value in Chilota Lambs
}

\author{
Desarrollo de la Morfoestructura y el Valor Carnicero en Corderos Chilotes
}

\author{
"R. de la Barra; "M. E. Martínez; ${ }^{*}$ C. Calderón; ${ }^{* *}$ R. Morales \& ${ }^{* * *}$ L. F. de la Fuente
}

DE LA BARRA, R.; MARTínez, M. E.; CALDERón, C.; MORAlES, R. \& DE LA FUENTE, L. F. Development of the morphostructure and meat value in chilota lambs. Int. J. Morphol., 30(4):1538-1543, 2012.

SUMMARY: Chilota sheep are typical of the Chiloé archipelago in southern Chile. The objectives of this study were: 1) To describe the development of the morphostructure of Chilota lambs in their first months of life using some variables that determine lamb meat value (zoometric traits and body weight) and 2) To determine the optimum slaughter age. Measurements were taken from 12 male single-born lambs. Body weight, Withers height; Perimeter of thorax, Chest depth, Shoulder point width and Body length were measured in each animal. The first measurements were taken at 7 days old, and the rest at 37, 67, 97, 127, 157 and 187 days old. The body weight variables and zoometric traits developed allometrically throughout the growth phase. The correlation coefficient between all the traits was very high, varying between 0.91 and 0.98 . The zoometric variable that best predicted body weight was Perimeter of thorax ( $\mathrm{r} 2=0.93)$, which was fully developed in $90 \%$ of the animals at 97 days old. Maximum growth was recorded in all the studied variables during the first control month, days 7-37, but then it decreased gradually. This decrease was moderate until day 127 , becoming very low from then on until end of the study. The optimum age for slaughtering fattened lambs is approximately four months, as from day 127 the daily growth rate slows down considerably, to $61.81 \mathrm{~g} / \mathrm{day}$, in comparison with the previous stage, which is $220.00 \mathrm{~g} / \mathrm{day}$. Therefore, the maintenance of lambs after four months is not productively efficient.

KEY WORDS: Sheep; Postnatal development; Morphology; Body weight.

\section{INTRODUCTION}

The Chilota sheep population is typical of the Chiloé archipelago in southern Chile. This breed is not autochthonous in the archipelago, and was possibly first introduced by Spanish conquerors from 1568. Currently, the total estimated population is 40,000 heads (De la Barra et al., 2011). In 2010, Chilota was officially recognised as the first ovine breed in Chile, with a high conservation value as a result of its contribution to the genetic variability of sheep breeds in the country (De la Barra et al., 2010). Also, the first studies carried out on its productive value indicate that it is a very hardy breed with regard to feeding and health (Calderón et al., 2011; Martínez et al., 2010, 2011a) and has potential for milk production (Martínez et al., 2011b). However, the Chilota breed has traditionally been reared for lamb meat production as part of the tourist offer in the Chiloé archipelago. Knowledge of the growth process in the Chilota lamb during its first months of life would be very useful for determining the optimum slaughter age and taking full advantage of the animal's growth, and eventually, ewe milk production.

The objectives of this study were: 1) To describe the development of the morphostructure of Chilota lambs in their first months of life using some variables that determine lamb meat value (zoometric traits and body weight) and 2) To determine the optimum slaughter age.

\section{MATERIAL AND METHOD}

A sample of 12 male Chilota lambs was used in the study. The lambs came from a group of 40 three year-old ewes kept under a common management system from heat

\footnotetext{
* Instituto de Investigaciones Agropecuarias (INIA), Centro Experimental Butalcura, Chiloé, Chile.

${ }^{* *}$ Instituto de Investigaciones Agropecuarias (INIA), Centro Regional Remehue, Osorno, Chile

*** Departamento de Producción Animal, Universidad de León, España.

This work was founded by the Project "Recuperación y Desarrollo Ovino para la Provincia de Chiloé", Regional Governement of Los Lagos, IDI Code: 30080533-0.
} 
to weaning at 90 days post partum. The lambs were all the same age, born in single births within 48 hours to ewes with synchronised oestrus. The lambs were separated from their mothers at ninety days old and kept together in natural pasture until 180 days old. The recorded traits were: body weight (BW), perimeter of thorax (PT), chest depth (CD), shoulder point width (SW) and body length (BL). Measurements were taken every month, when the lambs were 7, 37, 67, 97, 127, 157 and 187 days old. These body measurements, related to meat value, had been used in previous studies (Álvarez et al., 2000; Espinace, 2009; Calderón et al., 2009; Bravo \& Sepúlveda, 2010; De la Barra et al., 2011). Tape measure, a compass and a skin fold calliper were used to measure the traits. ADG was measured by means of a field scale. Statistical analysis was done with the SAS program and GLM, REG and CORR procedures (SAS, Cary Inc). In the analytical model, the dependent variables were the body measurements and the independent variable was age.

\section{RESULTS AND DISCUSSION}

A lamb's body resembles the dimensions of a cylinder where length, width and depth roughly define the volume (Bravo \& Sepúlveda; Toro et al., 2010).

Table I shows the basic statistics of body weight and morphological measurements in the lambs. The graph in figure 1 shows how these body traits evolved. All of the body weight and zoometric trait variables can be seen to develop in a similar way. Figure1 shows how all the traits developed allometrically. The coefficient of correlation between all traits was very high, ranging from 0.91 to 0.98 due to a common underlying factor of variation, which was age. As the evolution of all the variables was closely correlated, an overall analysis of growth for all traits will be carried out later.
The prediction of body weight via linear regression with the body measurements following a forward selection method showed that PT $\left(r^{2}=0.93\right)$ was the zoometric measure that best predicted body weight. The next best traits were SW and CD with a partial $\mathrm{r}^{2}$ of 0.017 and 0.004 , respectively, their contribution to the prediction being less important.

The mean monthly growth rate for each trait according to the age of the lamb is shown in Table II. An ANOVA for these characters, with month, 6 levels, as the variation factor, was done to compare monthly growth. The results are shown in Table III.

Table II shows rapid initial growth when the animal was very young, which decreased until it reached the adult stage. Maximum growth was recorded between the first 7 37 days of life and then decreased progressively. This decrease occurred in two or three stages depending on the trait, being moderate until day 127 and then very low until the end of the test.

The results of the ANOVA for all traits can be seen in Table III. There are significant differences between monthly growth, the highest occurring in the youngest stages, particularly from birth to 97 or 127 days depending on the trait being considered.

Significant differences are observed between three stages ( $a, b$ and $c)$. The first stage (a) corresponds to the 737-day interval, with maximum values for growth, in comparison with the following stages where values were lower, except for BL with maximum growth during the first two months, days 7-67.

The second stage of growth (b) in some variables such as PT and CD lasted a month (days 37-67). In others, namely WH and SW, growth lasted two months (days 3797) and in others such as BW it lasted 3 months (days 37-

Table I. Descriptive statistics of body weight and morphological traits in Chilota lambs $(\mathrm{n}=12)$.

\begin{tabular}{lccccccc}
\hline \multirow{2}{*}{ Trait* } & \multicolumn{7}{c}{ Age (d) } \\
\cline { 2 - 8 } & $\mathbf{7}$ & $\mathbf{3 7}$ & $\mathbf{6 7}$ & $\mathbf{9 7}$ & $\mathbf{1 2 7}$ & $\mathbf{1 5 7}$ & $\mathbf{1 8 7}$ \\
\cline { 2 - 8 } & $\mathbf{M e a n} \pm$ SE & Mean \pm SE & Mean \pm SE & Mean \pm SE & Mean \pm SE & Mean \pm SE & Mean \pm SE \\
\hline BW (kg) & $3.81 \pm 0.26$ & $13.36 \pm 0.32$ & $19.85 \pm 0.58$ & $25.50 \pm 0.75$ & $30.20 \pm 0.71$ & $31.78 \pm 0.66$ & $33.91 \pm 0.53$ \\
WH (cm) & $33.11 \pm 0.69$ & $45.13 \pm 0.36$ & $52.33 \pm 0.37$ & $54.29 \pm 0.32$ & $58.32 \pm 0.52$ & $58.66 \pm 0.50$ & $59.62 \pm 0.39$ \\
PT (cm) & $36.65 \pm 1.06$ & $55.58 \pm 0.64$ & $65.41 \pm 0.91$ & $69.41 \pm 0.88$ & $72.05 \pm 0.80$ & $74.66 \pm 0.74$ & $78.24 \pm 0.88$ \\
CD (cm) & $12.42 \pm 0.29$ & $17.58 \pm 0.26$ & $20.58 \pm 0.23$ & $24.27 \pm 0.37$ & $24.45 \pm 0.29$ & $24.78 \pm 0.41$ & $25.79 \pm 0.58$ \\
SW (cm) & $8.13 \pm 0.32$ & $13.37 \pm 0.36$ & $16.33 \pm 0.48$ & $19.56 \pm 0.40$ & $20.79 \pm 0.44$ & $21.54 \pm 0.47$ & $22.71 \pm 0.28$ \\
BL (cm) & $26.68 \pm 0.71$ & $39.58 \pm 0.37$ & $51.58 \pm 0.64$ & $55.40 \pm 0.61$ & $58.41 \pm 0.53$ & $59.45 \pm 0.31$ & $61.55 \pm 0.25$ \\
\hline
\end{tabular}

*BW: Body weight; WH: Withers height; PT: Perimeter of thorax; CD: Chest depth; SW: Shoulder point width; BL: Body length. 
Table II. Growth of body weight and morphological traits in Chilota lambs $(n=12)$.

\begin{tabular}{lcccccc}
\hline \multirow{2}{*}{ Trait* } & \multicolumn{5}{c}{ Age (d) } \\
\cline { 2 - 7 } & $7-37$ & $37-67$ & $67-97$ & $97-127$ & $127-157$ & $157-187$ \\
\cline { 2 - 7 } ADG (g/d) & $318.61 \pm 15.61^{\mathrm{a}}$ & $216.11 \pm 14.31^{\mathrm{b}}$ & $188.61 \pm 9.70^{\mathrm{b}}$ & $156.66 \pm 19.24 \mathrm{~b}$ & $52.50 \pm 8.13 \mathrm{c}$ & $71.11 \pm 19.11^{\mathrm{c}}$ \\
BW (kg) & $9.55 \pm 0.47^{\mathrm{a}}$ & $6.48 \pm 0.43 \mathrm{~b}$ & $5.66 \pm 0.29 \mathrm{~b}$ & $4.70 \pm 0.58 \mathrm{~b}$ & $1.58 \pm 0.24 \mathrm{c}$ & $2.13 \pm 0.57 \mathrm{c}$ \\
WH (cm) & $12.02 \pm 0.86^{\mathrm{a}}$ & $7.20 \pm 0.49 \mathrm{~b}$ & $1.96 \pm 0.27 \mathrm{~b}$ & $4.03 \pm 0.50 \mathrm{c}$ & $0.34 \pm 0.18 \mathrm{c}$ & $0.96 \pm 0.30 \mathrm{c}$ \\
PT (cm) & $18.93 \pm 1.54 \mathrm{a}$ & $9.83 \pm 0.84 \mathrm{~b}$ & $4.00 \pm 0.76 \mathrm{c}$ & $2.64 \pm 0.41 \mathrm{c}$ & $2.61 \pm 0.65 \mathrm{c}$ & $3.58 \pm 0.58 \mathrm{c}$ \\
CD (cm) & $5.16 \pm 0.47^{\mathrm{a}}$ & $3.80 \pm 0.43 \mathrm{~b}$ & $1.98 \pm 0.29 \mathrm{c}$ & $0.72 \pm 0.24 \mathrm{~d}$ & $0.90 \pm 0.21 \mathrm{~d}$ & $0.64 \pm 0.54 \mathrm{~d}$ \\
SW (cm) & $5.24 \pm 0.54^{\mathrm{a}}$ & $3.00 \pm 0.29 \mathrm{~b}$ & $3.69 \pm 0.29 \mathrm{~b}$ & $0.18 \pm 0.29 \mathrm{c}$ & $0.33 \pm 0.18 \mathrm{c}$ & $1.01 \pm 0.28 \mathrm{c}$ \\
BL (cm) & $12.90 \pm 0.82 \mathrm{a}$ & $12.00 \pm 0.74 \mathrm{a}$ & $3.81 \pm 0.38 \mathrm{~b}$ & $3.01 \pm 0.72 \mathrm{~b}$ & $1.04 \pm 0.48 \mathrm{c}$ & $2.10 \pm 0.42 \mathrm{c}$ \\
\hline
\end{tabular}

* ADG: Average daily gain, BW: Body weight; WH: Withers height; PT: Perimeter of thorax; CD: Chest depth; SW: Shoulder width; BL: Body length. a-d, Means in the same row with different superscripts differ $(P<0.05)$.

Table III. Analysis of variance for the month effect.

\begin{tabular}{lcccc}
\hline Trait $*$ & DF & F value & Pr $>$ F & R2 \\
\hline BW $(\mathbf{k g})$ & 5 & 43.10 & $<0.0001$ & 0.76 \\
WH $(\mathbf{c m})$ & 5 & 84.10 & $<0.0001$ & 0.87 \\
PT $(\mathbf{c m})$ & 5 & 54.70 & $<0.0001$ & 0.80 \\
CD $(\mathbf{c m})$ & 5 & 29.06 & $<0.0001$ & 0.69 \\
SW $(\mathbf{c m})$ & 5 & 26.83 & $<0.0001$ & 0.67 \\
BL $(\mathbf{c m})$ & 5 & 81.73 & $<0.0001$ & 0.86 \\
\hline
\end{tabular}

*BW: Body weight; WH: Withers height; PT: Perimeter of thorax; CD: Chest depth; SW: Shoulder width; BL: Body length.
127). The growth rate in the third stage (c) was very low, occurring from day 127 (SW and CD) in some, and from day 157 in the rest. As can be seen in Figure 1, all body measurements for the Chilota breed follow a similar pattern of growth, which is rapid in the first month of life, reaching $318 \mathrm{~g} / \mathrm{d}$ ADG and then slows down, as occurs in other breeds (Abassa et al., 1992), with a very low ADG of $61.81 \mathrm{~g} / \mathrm{d}$ from day 127.

Another way of measuring growth described in this discussion is by comparing the percentage of the value of

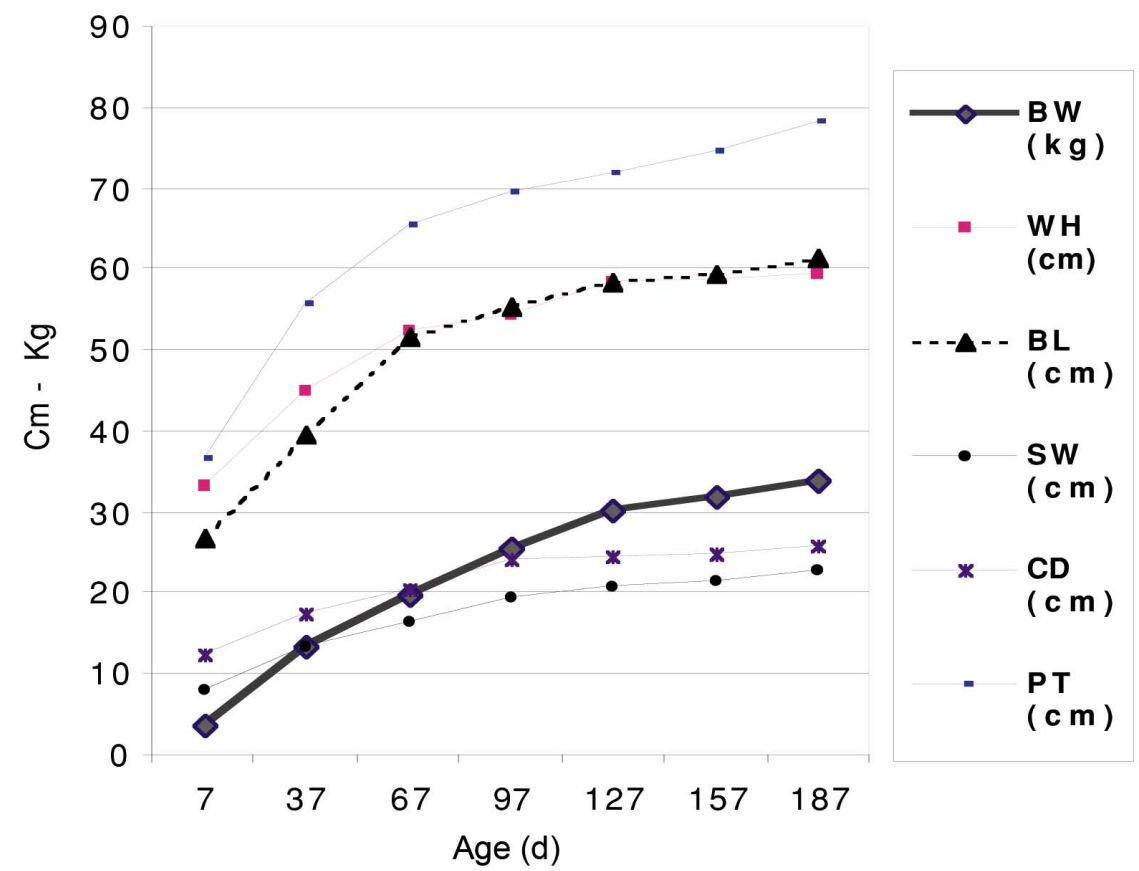

Fig. 1.Monthly evolutionof body weight and zoometric traits in Chilota lambs. BW: Body weight; WH: Withers height; BL: Body length; SW: Shoulder width; CD: Chest depth; PT: Perimeter of thorax. 
each trait with the value in the adult animal, based on data for Chilota breed published by De la Barra et al. (2011).

The growth curve pattern for each measure is very similar, which indicates fairly allometric growth, but it is not identical for all variables. Growth is very rapid for $\mathrm{WH}$ and BL; by 127 days they had already reached $97 \%$ and 94\% of the value corresponding to adult animals, respectively. However, growth in other traits was not so rapid, $\mathrm{CD}$ and SD reaching $74 \%$ and $77 \%$ of the measures for adults, respectively, at 127 days old.

The results are coincident with those for expected development, where structural measurements such as height and length increase first, followed by an increase in measurements associated with fattening traits such as chest and rump width.

Although all the measurements are closely correlated ( $r$ between 0.91 and 0.98 ), when a forward regressionwas made, the zoometric measurement that best predicted body weight was PT, which is undoubtedly a good estimator of overall body growth. Including other variables in the regression does not improve accuracy. In this sense, PT is closely related to meat value and is the main descriptor of a morphostructure that favours greater meat yield (Herrera et al., 1996).
In the Chilota breed, all of the variables show rapid growth during the first days of life, thoracic perimeter reaching $83 \%$ of the measure corresponding to the adult at 67 days, $90 \%$ at 97 days and $92 \%$ at 127 days. Although morphological development is complete relatively early, development in BW is slightly more delayed, $65 \%$ at 127 days. Although a lamb's body is defined by its spatial dimensions (length, height and width), weight and carcass yield, and therefore meat value, are in fact determined by muscular development in the morphostructural matrix (Sañudo, 2008; Sanz et al., 2008; Bravo et al., 2010; Barcelos et al., 2010).

Chilota lambs are normally slaughtered at $150-180$ days old, as occurs with other introduced breeds, because they reach their maximum weight at this age (Shrestha et al., 1982, 2007; Stanford et al., 1996; Hammel \& Laforest, 1999; Teixeira et al., 2004).

As Chilota lambs mature earlier, they should be slaughtered at 120-150 days, or even before depending on the type of carcass being produced. Miguélez et al. (2007), state that in Spanish ovine breeds, slaughter at an early age makes a noticeable difference to the organoleptic quality of lamb meat in comparison with slaughter at a later age. Luaces et al. (2007) indicate that in Spanish breeds, the lower the slaughter age, the greater the proportion of muscle and bones,

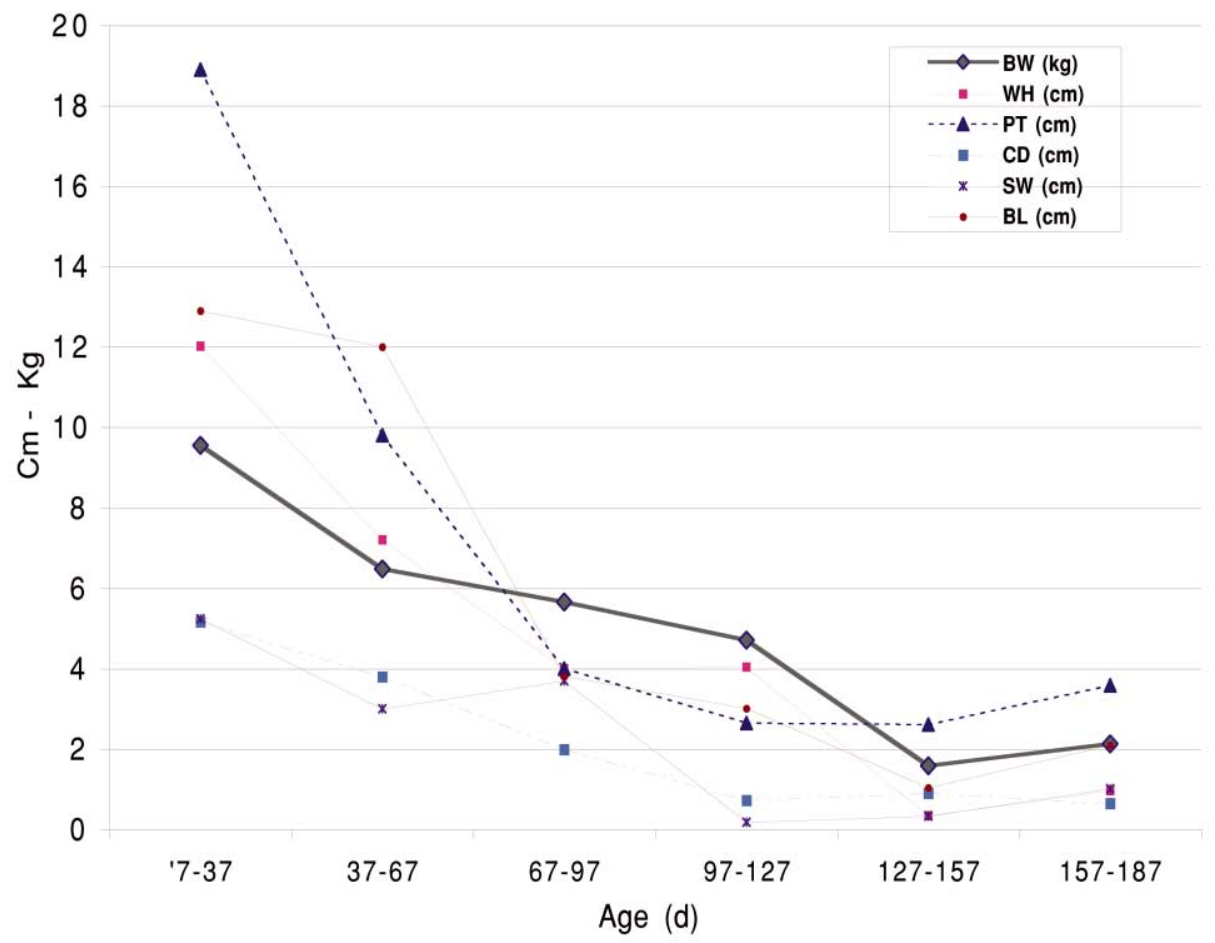

Fig. 2. Monthly growth of body weight and zoometric traits in Chilota lambs. BW: Body weight; WH: Withers height; PT: Perimeter of thorax; CD: Chest depth; SW: Shoulder width; BL: Body length. 
whereas the higher the slaughter age the greater the proportion of fat.

Given the rate of growth in Chilota lambs until 6797 days of age, the production of lambs for early slaughter appears to be an interesting option, as by that age they have reached a considerable size. Also, the meat is good quality and of great commercial value due to having a lower proportion of fat.

On the other hand, if a heavier lamb is required, the ideal slaughter age is approximately 4 months, as the daily growth rate after day 127 is very low, $61.81 \mathrm{~g} /$ day, in comparison with $220.00 \mathrm{~g} /$ day in the previous stage. Slaughter lambs after 4 months of age is not productive efficient, and could be not economically attractive as costs could exceed any profit generated.
If we consider zoometric variables as well as the growth rate, the conclusions are similar. BL and TP are the relevant defining lamb carcass traits, as well as yield in high value cuts such as the loin (Stanford et al.; Capenter \& Cocket, 2000; Sañudo). In this study, the results obtained for BL and PT show that at 127 days growth accounts for $94 \%$ and $92 \%$ of the adult stage, respectively. Any gain after day 127 is low, which is in accordance with the idea of slaughter at approximately 4 months.

SW showed the lowest rate of development, $77 \%$, after 127 days. However, this measurement is not associated with the commercial value of the carcass and is therefore not an important predictor of its economical value. Also, growth in the later stages is associated with larger fat deposits and is not desirable for the commercial value of the carcass.

DE LA BARRA, R.; MARTÍNEZ, M. E.; CALDERÓN, C.; MORALES, R. \& DE LA FUENTE, L. F. Desarrollo de la morfoestructura y el valor carnicero en corderos chilotes. IInt. J. Morphol., 30(4):1538-1543, 2012.

RESUMEN: La oveja Chilota es una raza típica del archipiélago de Chiloé en el sur de Chile. Se midieron 12 corderos machos nacidos de parto único. En cada animal se midieronel peso corporal, la alzada a la cruz, el perímetro del tórax, diámetro dorso esternal, diámetro bicostal y la longitud corporal. Las primeras mediciones se tomaron a los 7 días de edad, y el resto a los 37, 67, 97, 127, 157 y 187 días de edad. El peso corporal y los rasgos zoométricos se desarrollaron alométricamente a lo largo de la fase de crecimiento. El coeficiente de correlaciónentre todos los rasgos fue muy elevado, variando entre 0,91 y 0,98 . La variable zoométrica mejor predicha por el peso corporal fue el perímetro torácico ( $2=0,93$ ), el cual estuvo totalmente desarrollado en el $90 \%$ de los animales a los 97 días de edad. El crecimiento máximo fue registrado durante el primer mes de control (días 7-37) para todas las variables estudiadas, pero posteriormente decreció de forma gradual. Este decrecimiento fue moderado hasta el día 127, volviéndose muy lento hacia el final del estudio. La edad óptima para el sacrificio de los corderos es aproximadamente de 4 meses, dado que a partir del día 127 la tasa diaria de crecimiento disminuye considerablemente, a 61,81 g/día, en comparación con la etapa previa, donde esta tasa es de 220,00 g/día.Por lo tanto, el sacrificio de los corderos más allá de los 4 meses de edad no resulta productivamente eficiente.

PALABRAS CLAVE: Ovino; Desarrollo postnatal; Morfología; Peso corporal.

\section{REFERENCES}

Abassa, K. P.; Pessinaba, J. \& Adeshola-Ishola, A. Croissance présevrage des agneaux Djallonké au centre de Kolokopé (Togo). Rev. Élev. Méd. Vét. Pays Trop., 45(1):49-54, 1992.

Álvarez, S.; Fresno, M.; Capote, J.; Delgado, J. \& Barba, C. Estudio para la caracterización de la raza ovina Canaria. Arch. Zootec., 49(185-186):209-15, 2000.

Bravo, S. \& Sepúlveda, N. Índices zoométricos en ovinos criollos Araucanos. Int. J. Morphol., 28(2):489-95, 2010.

Bravo, S.; Fabres, M.; Schnettler, B. \& Sepúlveda, N. Corporal composition and characterisitics of carcass of Araucano Creole Lambs. Int. J. Morphol., 28(4):1107-11, 2010.

Barcelos, D.; Cassol, C.; Pfüller, T.; de Oliveira, F.; Petrarca, G. \& Griebler, L. Postweaning growth of the non-carcass components of Texel crossbred lambs. R. Bras. Zootec., 39(7):1558-64, 2010.

Calderón, C.; De la Barra, R.; Martínez, M. E. \& Gonzalo, C. Variabilidad fenotípica morfoestructural de las razas ovinas predominantes en Chiloé. VII Simposio de recursos genéticos para América latina y el Caribe (SIRGEALC), Pucón, Chile, 2009.

Calderón, C.; De la Barra, R.; Uribe, H. \& Martínez, M. E. Susceptibilidad a afecciones podales en ovejas de raza Chilota, RomneyMarsh y Suffolk Down. XXXVI Congreso de la Sociedad Chilena de producción animal. Punta Arenas, Chile, 2011. pp.19-20.

Carpenter, C. \& Cockett, N. Histology of longissimus muscle from 2-week-old and8-week-old normal and callipyge lambs. Can. J. Anim. Sci., 80(3):511-4, 2000. 
De la Barra, R.; Uribe, H.; Latorre, E.; Aranz, J. J. \& San Pimitivo, F. Genetic structure and diversity of four Chilean sheep breeds. Chilean J. Agric. Res., 70(4):646-51, 2010.

De la Barra, R.; Carvajal, A.; Uribe, H.; Martínez, M. E.; Gonzalo, C.; Arranz, J. J. \& San Primitivo, F. El ovino criollo Chilote y su potencial productivo. Anim. Genet. Resour., 48:93-9, 2011.

Espinace, B. Evaluación etnológica de la raza Suffolk Down en Chile. Tesis de grado para Médico Veterinario, Puerto Montt, Chile, Universidad Santo Tomás, 2009. p.85.

Hammell, K. \& Laforest, J. Evaluation of the growth performance and carcass characteristics of lambs produced in Quebec. Can. J. Anim. Sci., 80(1):25-33, 1999.

Herrera, M.; Rodero, E.; Gutiérrez, M. J.; Peña, F. \& Rodero, J. Application of multifactorial discriminant analysis in the morphostructural differentiation of Andalusiancaprine breeds. Small Ruminant Res., 22(1):39-47, 1996.

Luaces, M. L.; Calvo, C.; Fernández, B.; Fernández, A.; Viana, J. \& Sánchez, L. Alometría de los tejidos en corderos de raza ovina gallega. ITEA, 103(2):72-83, 2007.

Martínez, M. E.; Calderón, C.; De la Barra, R.; De la Fuente, F. \& Gonzalo C. Uddermorphologicaltraits and milkyield of Chilota and Suffolk sheepbreeds. Chilean J. Agric. Res., 71(1):90-5, 2011a.

Martínez, M. E.; de la Barra, R.; Uribe, H. \& Calderón, C. Efecto de diferentes niveles de desparasitación en el peso al destete de corderos de raza ovina Chilota, RomneyMarsh y Suffolk Down. Punta Arenas, Chile, XXXVI Congreso de la Sociedad Chilena de producción animal, 2011b. pp.13-4.

Miguélez, E.; Zumalacárregui, J.; Osorio, M. \& Mateo, J. Características de la canal de cordero lechal de diversas razas producidas en España. ITEA, 103(1):14-30, 2007.

Sañudo, C. Carcass and meat lamb and kid quality and development of consumer acceptability. R. Bras. Zootec., 37:143-60, 2008.

Sanz, J.; Álvarez-Rodriguez, L.; Cascarosa, G.; Ripoll, S.; Carrasco, R. \& Revilla, M. Características de la canal de los tipos de los tipos comerciales de cordero Lechal, Ternasco y Pastenco de la raza Churra Tensina. ITEA, 104(1):42-57, 2008.

Shrestha, J.; Petersi, H. \& Heaney, D. Growth performance of lambs sired by rams of the East Friesian, Finnish Landrace, Ile de France and Suffolk breeds. Can. J. Anim. Sci., 62:689-97, 1982.

Shrestha, J.; Boylan, W. \& Rempel, W. Evaluation of sheep genetic resources in North America: Lamb productivity of purebred, crossbred and synthetic populations. Can. J. Anim. Sci., 88:3918, 2007.

Stanford. K.; Woloschuk, C. M.; McClelland, L. A.; Jones, S. D.
M. \& Price, M. A. Comparison of objective external carcass measurements and subjective conformation scores for prediction of lamb carcass quality. Can. J. Anim. Sci., 77:21723, 1996.

Teixeira, A.; Delfa, R.; Cadavez, V. \& Bueno, M. S. Carcass conformation and joints composition of Churra Galega Bragançana and crossbred lambs by Suffolk and Merino Precoce sire breeds. Span. J. Agric. Res., 2(2):217-26, 2004.

Toro, I. M. V.; Manríquez, S. G. \& Suazo, G. I. Morfometría geométrica y el estudio de las formas biológicas: De la morfología descriptiva a la morfología cuantitativa. Int. J. Morphol., 28(4):977-90, 2010.

\section{Correspondence to:}

M. E. Martínez

Instituto de Investigaciones Agropecuarias (INIA)

Centro Experimental Butalcura, Chiloé

CHILE

Tel: $+56-65-630656$

Email: mariae.martinez@inia.cl

Received: 20-04-2012

Accepted: 04-09-2012 